\section{Environmental Impacts of the Coal Ash Spill in Kingston, Tennessee: An 18-Month Survey}

\author{
LAURA RUHL, ${ }^{\dagger}$ AVNER VENGOSH, ${ }^{*},{ }^{\dagger}$ \\ GARY S. DWYER, ${ }^{\dagger}$ HEILEEN HSU-KIM, ${ }^{\ddagger}$ \\ AND AMRIKA DEONARINE \\ Division of Earth and Ocean Sciences, Nicholas School of the \\ Environment, 205 Old Chemistry Building, Box 90227, Duke \\ University, Durham, North Carolina 27708, United States, \\ and Civil and Environmental Engineering, 121 Hudson Hall, \\ Box 90287, Duke University, Durham, \\ North Carolina 27708, United States
}

Received August 5, 2010. Revised manuscript received October 5, 2010. Accepted November 3, 2010.

An 18 month investigation of the environmental impacts of the Tennessee Valley Authority (TVA) coal ash spill in Kingston, Tennessee combined with leaching experiments on the spilled TVA coal ash have revealed that leachable coal ash contaminants (LCACs), particularly arsenic, selenium, boron, strontium, and barium, have different effects on the quality of impacted environments. While LCACs levels in the downstream river water are relatively low and below the EPA drinking water and ecological thresholds, elevated levels were found in surface water with restricted water exchange and in pore water extracted from the river sediments downstream from the spill. The high concentration of arsenic (up to $2000 \mu \mathrm{g} / \mathrm{L}$ ) is associated with some degree of anoxic conditions and predominance of the reduced arsenic species (arsenite) in the pore waters. Laboratory leaching simulations show that the $\mathrm{pH}$ and ash/water ratio control the LCACs' abundance and geochemical composition of the impacted water. These results have important implications for the prediction of the fate and migration of LCACs in the environment, particularly for the storage of coal combustion residues (CCRs) in holding ponds and landfills, and any potential CCRs effluents leakage into lakes, rivers, and other aquatic systems.

\section{Introduction}

On December 22, 2008, the Kingston coal-fired power plant of Tennessee Valley Authority (TVA) had a containment structure rupture, spilling over 3.7 million cubic meters of wet coal ash (fly ash with intermixed bottom ash), inundating the Emory River, its tributaries, and the adjacent landscape near Harriman, TN (1). The wet coal ash spilled into the Emory River, which joins the Clinch River, and then converges with the Tennessee River (Figure 1), a major drinking water source for populations downstream (2). Previous investigation has shown that the concentration of some leachable coal ash contaminants (LCACs) such as boron, arsenic, strontium, and barium increased slightly downstream of the spill relative to the upstream river concentrations, but

\footnotetext{
* Corresponding author: phone: (919) 681-8050; fax (919) 6845833; e-mail: vengosh@duke.edu.

${ }^{\dagger}$ Division of Earth and Ocean Sciences.

${ }^{\ddagger}$ Civil and Environmental Engineering.
}

remained below the EPA's maximum contaminant level (MCL) (3) and the continuous criterion concentration (CCC) (4) for aquatic life. However, areas of restricted water exchange (i.e., the "cove"; Figure 1), where water remained stagnant and in direct contact with coal combustion residues (CCRs), had high levels of LCACs (2).

The high concentrations of LCACs in CCRs (5-15) and their enhanced mobility in aquatic systems $(16-18)$ are the key factors for evaluating potential risks of CCRs to the environment. The TVA spill has provided a unique opportunity to examine these effects on a regional field scale, beyond laboratory leaching tests $(1,19-23)$. The objectives of this study are (1) to provide a systematic 18-month monitoring survey of the environmental impacts following the TVA coal ash spill in Kingston, Tennessee; (2) to examine the composition of major constituents and trace metals in water samples from different sites associated with the ash spill, including upstream and downstream river waters, tributary waters, and porewater extracted from the river sediments; (3) to conduct laboratory leaching experiments on the TVA coal ash for evaluating the factors that control LCACs composition and mobilization; (4) to examine the possible river quality impacts upon dredging of the ash from the rivers, which was part of the major remediation plan by TVA (1); and (5) to evaluate the impact of redox conditions that prevail in river sediments on the reactivity of coal ash in the environment, particularly for arsenic mobilization and species distribution.

Analytical Methods. Twelve field trips were made to the spill site between January 2009 and June 2010 with over 220 surface and porewater samples collected during high (winter) and low (summer-fall) river flow regimes (Figure 2). Water sampling strictly followed U.S. Geological Survey (USGS) protocols (24); after filtration of samples in the field $(0.45 \mu \mathrm{m}$ syringe filters), trace elements were measured by inductively coupled plasma mass spectrometry (ICP-MS), major elements by direct current plasma optical emission spectrometry (DCPOES), and anions by ion chromatography (IC). Pore waters were extracted from river bottom sediments obtained using a Wildco box core (up to $25 \mathrm{~cm}$ depth) and VibeCore (up to $182 \mathrm{~cm}$ depth). Inorganic arsenic species were measured using the Bednar method (25) in which the uncharged arsenic species As ${ }^{\mathrm{III}}$ was separated from porewater and preserved in the field. Acid volatile sulfide (AVS) $(26,27)$ was quantified in whole sediment samples from the box core. Laboratoryleaching experiments were conducted on a bulk coal ash sample that was collected from the Cove area (Figure 1) soon after the spill. Leaching experiments were simulated reactions of the spilled TVA ash (Figure 1) with solutions exhibiting a wide range of acidity ( $\mathrm{pH}$ of $0.4-12$ ) and ash/water ratios $\left(1 \times 10^{-5}\right.$ to $\left.3.5 \times 10^{-3}\right)$.

\section{Results and Discussion}

Laboratory TVA Coal Ash Leaching. Two types of leaching experiments on the TVA coal ash were conducted: (1) leaching under different $\mathrm{pH}$ conditions; and (2) reaction with deionized water and an upstream Emory River water under different ash/water ratios (referred to as total suspended solids, TSS). Leaching simulations under a wide range of $\mathrm{pH}$ conditions resulted in differential LCAC leaching. As, B, Sr, and Se showed maximum dissolved concentrations in leachates under extreme acidic ( $\mathrm{pH} 0.4$ to 1.7) conditions. As and Se, and to much lesser extent $\mathrm{B}$, reached minimum concentrations at $\mathrm{pH}$ values between 4.5 and 7 , and then increased in leachate concentration at $\mathrm{pH}$ 12. Sr and Ca showed progressively lower 


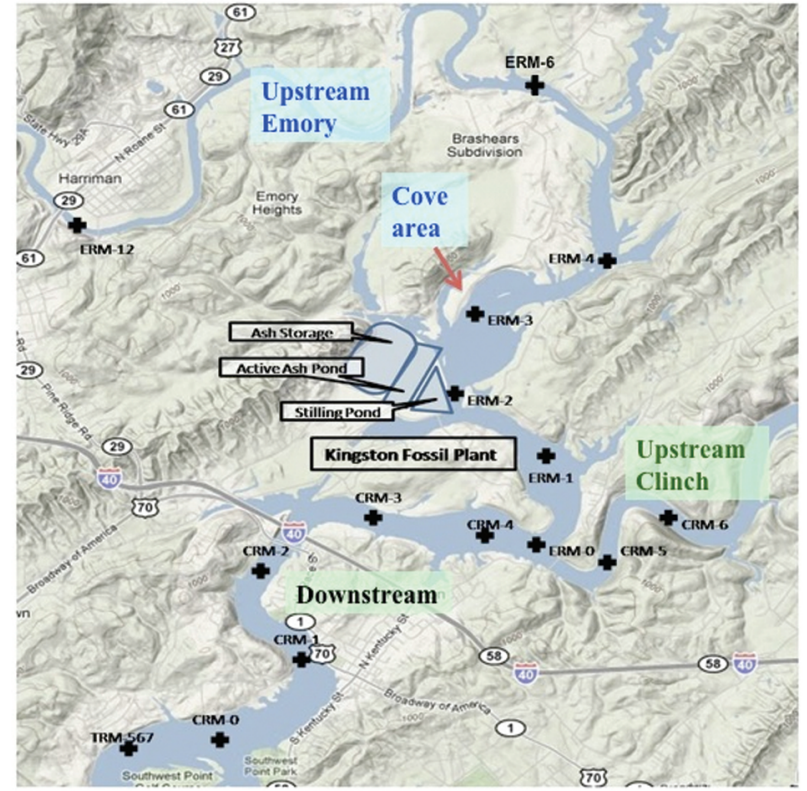

FIGURE 1. Map of spill site of the TVA Kingston Fossil Plant. Emory and Clinch River mile markers (ERM and CRM) are labeled. The possible extent of the spilled ash upstream continued to CRM 5 and ERM 6 due to the magnitude of the spill's initial force and altered hydrodynamics of the power plant water intake, and continued further downstream than shown on this map (due to subsequent storm events) (base map provided by Google maps).

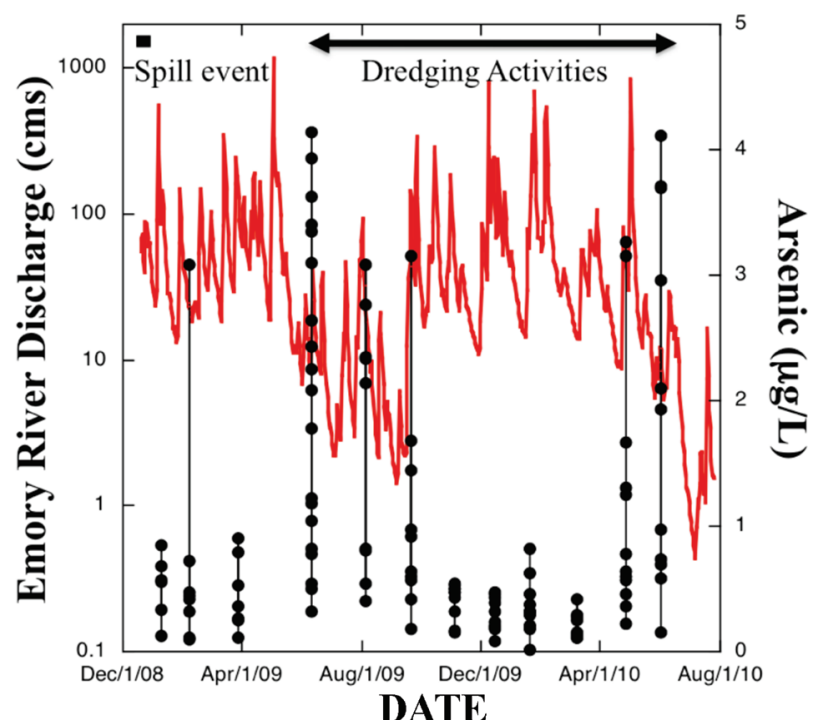

FIGURE 2. Variations of flow rate (cubic meters per second; red line, left-hand side axis) in the upstream Emory River USGS gauge at Oakdale, TN (28) and arsenic concentrations in downstream river water (black circles, right-hand side axis). Note that the low typical river discharges in the summer were associated with higher As concentrations in the downstream river water. Also note the timing of the spill event (black square) and dredging activities (arrow).

concentrations in leachates with increasing $\mathrm{pH}$. These results are consistent with previous laboratory leaching experiments $(19-23,29,30)$. The differential LCACs mobilization generated large variations in the contaminants' ratios (e.g., As/B, Se/As; Figure 3).

The second type of experiments showed that the TVA ash had low buffering capacity. The reaction of the ash with an upstream Emory river sample did not change the $\mathrm{pH}$ of the effluents, even at high ash/water ratios (Figure 3). This nonalkaline characteristic of the TVA coal ash is different from other CCRs reported elsewhere (19-23). Sensitivity tests for tracing LCACs upon reacting TVA ash with deionized water and upstream river water showed that $\mathrm{As}, \mathrm{Sr}, \mathrm{Ba}$, and to a lesser extent B were traceable even at low solid/water conditions. This result also reflects the sensitivity of the analytical method. The concentrations of these elements were linearly correlated with ash/water ratios up to $1 \times 10^{-3}$ (TSS $=1000 \mathrm{mg} / \mathrm{L}$ ). For As, the empirical linear slopes for the variations of As concentrations with TSS (at range $<1000$ $\mathrm{mg} / \mathrm{L}$ ) were $4 \times 10^{-3}$ and $1 \times 10^{-2} \mu \mathrm{g}$ As per mg TSS for river water and deionized water, respectively (Figure 3 ). The results also show that As concentrations above the MCL of $10 \mu \mathrm{g} / \mathrm{L}$ could be obtained above TSS values of 3000 and $1000 \mathrm{mg} / \mathrm{L}$ for river water and deionized water, respectively (Figure 3 ).

Surface Water. A small tributary that was dammed by the ash spill, creating a standing pond (the "Cove"; Figure 1), initially had relatively high concentrations of LCACs above the background levels measured in the upstream Emory and Clinch Rivers (Table 1) (2). During the physical removal of the ash, while inflowing water was temporally diverted around the Cove area, the concentration of LCACs decreased (e.g., As $86 \mu \mathrm{g} / \mathrm{L}$ in February 2009 to $5 \mu \mathrm{g} / \mathrm{L}$ in November 2009). The concentrations of LCACs in the downstream river were significantly lower than those found in the Cove (Table 1), but nonetheless higher than levels in the upstream Emory and Clinch Rivers for each sampling date. During the 18month survey, the As concentrations measured in the downstream river sites were all below the EPA's MCL and CCC thresholds (Figure 2).

The spatial and temporal distributions of As concentrations in the river surface water (Figure 4) showed some distinctive peaks during June, August, and September 2009 and again in April and June 2010 at sites located at and downstream of the spill region (ERM 3-ERM 1). In contrast, winter sampling periods resulted in low As concentrations, likely due to greater dilution by higher winter flows (Figure 2). Between March 20, 2009 and May 2010 over two million cubic meters of ash were dredged out from the river as part of the TVA remediation activities (31). The seasonal dependence of As concentrations in the downstream river water (Figure 4), combined with relatively constant and low As contents during the major dredging activities (fall and winter 2010), indicates that ash dredging had minimal, if any impacts on the river surface water quality. This observation is consistent with our lab experiments (Figure 3), in which TVA ash leaching under TSS conditions similar to those measured in the Clinch and Emory Rivers $(20-100 \mathrm{mg} / \mathrm{L}(32,33)$ caused only a minor As contribution $(0.5-1 \mu \mathrm{g} / \mathrm{L})$.

Sediment Acid Volatile Sulfide (AVS). AVS was detected in the surface bottom river sediments (composite of the top $20-25 \mathrm{~cm}$ ) in all sites, with concentrations ranging from 0.02 $\mu \mathrm{mol} \mathrm{g}{ }^{-1}$ to $1.5 \mu \mathrm{mol} \mathrm{g}^{-1}$ (dry weight basis). No seasonal or spatial trends were observed over the course of sampling.

Pore Water. The huge quantity of released ash inundated many parts of the river and was found at significant distances upstream and downstream of the spill. The spill occurred at approximately Emory River mile 2.5 (ERM 2.5), and following redistribution by subsequent rain events, TVA investigations indicated the extent of ash from ERM 0.0 up to about ERM $6(9.6 \mathrm{~km})$, from Clinch River mile (CRM) 0.0 to about CRM $5(8 \mathrm{~km})$, and from Tennessee River Mile (TRM) 561.8 to TRM 568.7 with traces extending about $3.2 \mathrm{~km}$ downstream beyond TRM 561.8 (34) (Figure 1). The ash was distributed in the river either by the large force of the initial spill flow, the hydrodynamics of the power plant's water intake changing direction of river flow near the confluence of the Emory and 
Solid/water ratio
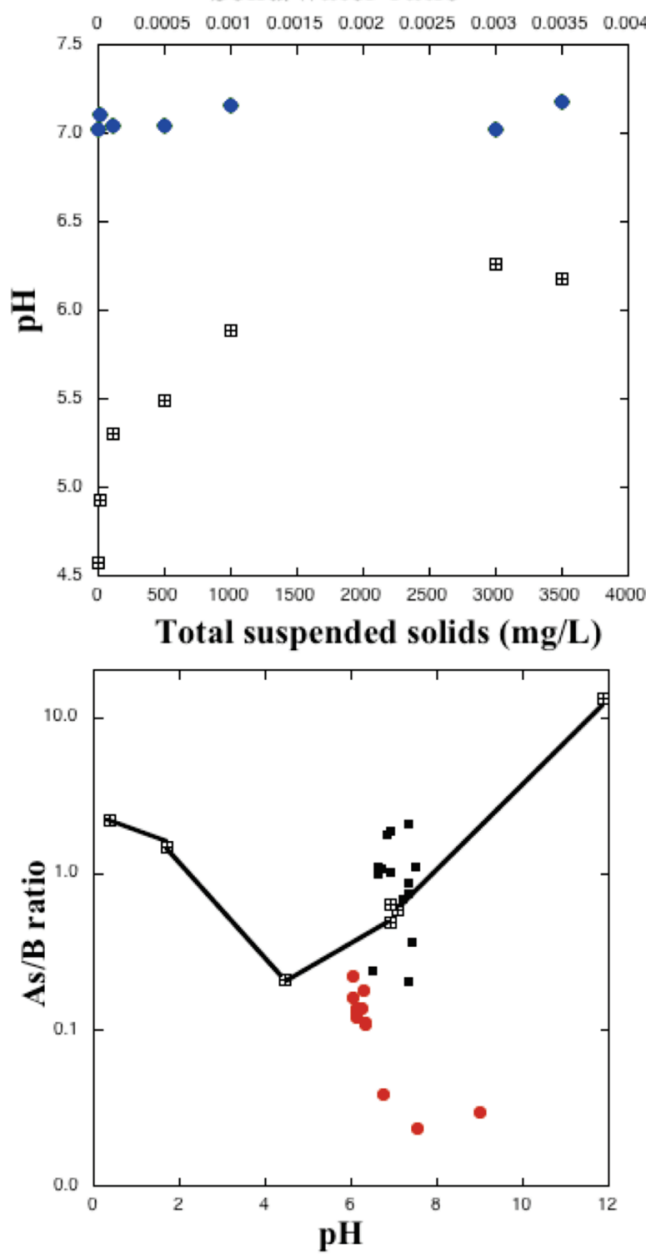

Solid/water ratio
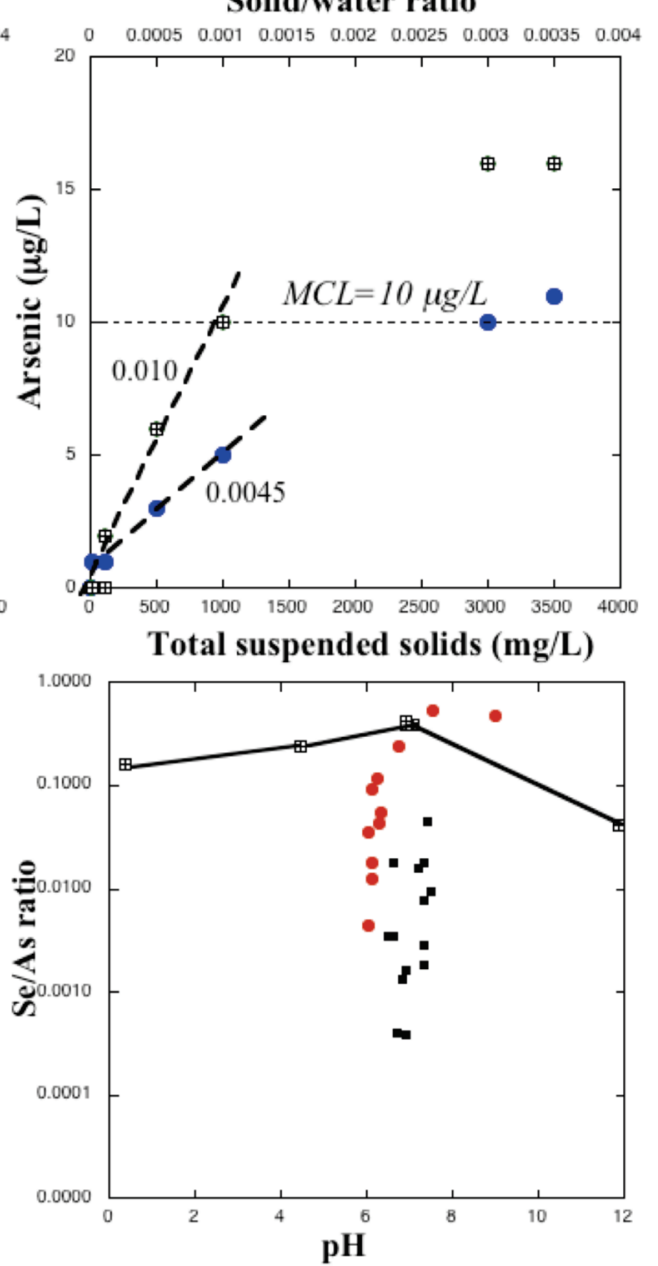

FIGURE 3. Results of leaching experiments of TVA coal ash under different ash/water ratios (upper panel) and pH conditions (lower panel). Variations of solid to water ratios, which are also expressed as total suspended solids (TSS), show different pH effects and As concentrations in the deionized water (checkered symbols, upper panel) and upstream Emory River (blue circles) leaching experiments. Slopes for the linear correlations up to TSS $=1000 \mathrm{mg} / \mathrm{L}$ are marked. $\mathrm{pH}$ variations show differential mobilization of LCACs in the experimental lechates (checkered symbols, lower panel), as compared to field measurements of pore water (black squares) and Cove water (red circles).

Clinch Rivers, and subsequent storm events (35). The spill region (ERM 3.0 to ERM 1.5) was characterized by deep deposits of ash, which formed the matrix for bottom sediment in this stretch of the river. Since the initial spill event, the ash has been washed further downstream, mixed with native sediment, and buried by fresh deposits of native sediments. Pore waters extracted from buried ash and native river sediment mixtures were found to have neutral-pH (a range of 6.6-7.4) and high concentrations of $\mathrm{B}, \mathrm{Sr}, \mathrm{Ba}$, and As relative to the upstream surface and pore waters (Table 1). The As concentrations (up to $2011 \mu \mathrm{g} / \mathrm{L}$; mean $=323.8 \pm 494 \mu \mathrm{g} / \mathrm{L}$ ) far exceeded the EPA's arsenic MCL $(10 \mu \mathrm{g} / \mathrm{L})$ and CCC (150 $\mu \mathrm{g} / \mathrm{L}$ ) for aquatic life. In contrast, concentrations of $\mathrm{Se}, \mathrm{Pb}$, $\mathrm{Cr}$, and $\mathrm{U}$ in the pore waters were low (Table 1).

The data show that pore water extracted from deep coring (sediment depth of $0-100 \mathrm{~cm}$ and $100-175 \mathrm{~cm}$ ) had significantly higher LCACs concentrations relative to shallow pore water (depth of $25 \mathrm{~cm}$ ) of the same sites (ERM 2 and CRM 4), suggesting that the deep pore water was a better representation of the internal sediment process, while the shallow pore water was likely affected by dilution from the overlying river water and/or oxidation during sampling. Nonetheless, high LCAC levels were also observed in the shallow pore waters (Table 1). Boron and strontium have been identified as good indicators for CCR leachates (2) (36-38), which is also confirmed by the leaching experiments performed in this study. A similar range of $\mathrm{B} / \mathrm{Sr}$ ratios were also observed in the artificial leaching experiments ( 0.55 to 0.85 at neutral $\mathrm{pH}$ ), the surface water region of limited water exchange (the Cove; $0.46-1: 00$ ), and pore water $(0.5-1.5)$. In contrast, the Se/As ratios show large variations, particularly for porewater with Se/As ratios $\left(2 \times 10^{-5}\right.$ to 0.10$)$ lower than those of the Cove $(0.01-0.53)$ and experimental leachates at neutral pH $(\sim 0.4)$ (Figures 3 and 5). Furthermore, As was enriched in the pore waters (As/B ratios $=0.1$ to 2.1) relative to the Cove waters $(0.02-0.22)$ and neutral-pH leachates $(\sim 0.6)$ (Figure 3$)$. In sum, we show that surface water from the Cove area had higher Se concentrations and Se/As ratios relative to the pore water, while the pore water had significantly higher As concentrations for similar B or $\mathrm{Sr}$ concentrations (i.e., higher As/B ratios; Figure 5).

Control of pH, Redox State, And Ash/Water Ratio on Contaminants' Mobilization. The sampling procedure of the pore water involved an exposure of the sediments and pore waters to the atmosphere. Thus, direct measurements of the redox state (e.g., redox potential and dissolved oxygen) of the pore water were not possible. However, we use the following observations to postulate that the river bottom sediments had some degree of a reducing state: (1) sulfate contents in the pore water (normalized to chloride; Figure 6) were significantly lower than that of the Cove water, suggesting the occurrence of sulfate reduction processes in 
the pore water; (2) the presence of acid volatile sulfide in the river sediments from which pore waters were extracted (0.01-0.9 $\mu \mathrm{mol} / \mathrm{g}$ ); (3) high concentrations of manganese and iron in pore waters relative to downstream river water (Table 1); and (4) direct measurement of the reduced form of arsenic (As ${ }^{\mathrm{III}}$ ) in the pore water (Figure 6).

Numerous studies have determined that the predominant species of arsenic and selenium in CCRs are the oxidized form arsenate $\left(\mathrm{As}^{\mathrm{V}}\right)$ and the reduced form selenite $\left(\mathrm{Se}^{\mathrm{IV}}\right)$, respectively (39-42). Based on the neutral-pH (6.6-7.4) and arsenic speciation measurements (Figure 6), we deduced that the uncharged $\mathrm{H}_{3} \mathrm{AsO}_{3}{ }^{0}$ species was the predominant species in the pore water. While the overall higher concentrations of As, B, and Sr in the pore water relative to the Cove water could reflect higher ash/water ratios, the differential enrichment of As in the pore water relative to the Cove water (Figures 3 and 5) could be due to the combination of (1) reductive dissolution of hydrous ferric oxides (HFO) and Mn-oxides (as evidenced by the high $\mathrm{Mn}$ and Fe contents in the pore water; Table 1) that could further release adsorbed As; and (2) decreased sorption of the uncharged $\mathrm{H}_{3} \mathrm{AsO}_{3}{ }^{0}$ species (compared to $\mathrm{As}^{\mathrm{V}}$ ) to the host sediments, including oxides, and sulfides $(43,44)$. Furthermore, we show that the relative As enrichment (i.e., an increase in As/B ratios) is associated with sulfate depletion in the pore water (lower $\mathrm{SO}_{4} / \mathrm{Cl}$ ratios; Figure 6), which suggests that the reducing conditions were sufficient to mobilize As but not as advanced to the stage for precipitation of arsenic sulfides $(25,45)$.

Conversely, the reduced Se species $\left(\mathrm{Se}^{\mathrm{IV}}\right)$ that was leached from CCRs was apparently preserved in the reducing conditions of the bottom sediments. Given the near neutral-pH of the pore water, we hypothesize that the predominant selenium species was $\mathrm{HSeO}_{3}{ }^{-}$, which is known to have a strong sorption affinity for both $\operatorname{HFO}(43,46)$ and clay minerals (47) that would result in lower Se concentrations in the pore waters. In oxidizing conditions, similar to the conditions in the restricted tributary (the Cove), $\mathrm{Se}^{\mathrm{IV}}$ that is leached from CCRs could be oxidized to $\mathrm{Se}^{\mathrm{VI}}$, which is less reactive toward sorption $(43,46)$. Therefore oxidation of selenium could result in relatively higher Se concentrations in surface waters; however, the kinetics of this transformation is rather slow (48). The apparent reduction of sulfate (Figure 6 ) is also associated with higher $\mathrm{Ba} / \mathrm{B}$ ratios in the pore water relative to the Cove surface water (Figure 5), thus suggesting higher Ba mobility in the pore water. One explanation for this enrichment could be the saturation state (SI) of the mineral Barite $\left(\mathrm{BaSO}_{4}\right)$, which would be significantly lower in the low-sulfate pore waters $\left(\mathrm{SI}_{\text {Barite }}=2.9\right)$ relative to highsulfate surface waters of the Cove $\left(\mathrm{SI}_{\mathrm{Barite}}=3.5\right)$.

The low Se/As and high As/B and $\mathrm{Ba} / \mathrm{B}$ ratios of the pore waters were distinctively different from those of the background upstream river water, whereas the downstream river samples had intermediate values (Figure 5). This apparent mixing relationship may indicate that the concentration of these elements in the downstream river water was not derived primarily from in situ interaction with suspended ash in the river but rather from subsurface LCAC-rich solutions that emerged from the river bottom. The level of LCAC concentrations in the river water depended therefore on the mass-balance between upstream river water and subsurface solutions rather than leaching from suspended ash in the river. A mass-balance calculation indicates that an increase from a background As concentration of $1 \mu \mathrm{g} / \mathrm{L}$ to a "contaminated" value of $5 \mu \mathrm{g} / \mathrm{L}$ in the downstream river would result from a contribution of only $0.2 \%$ of pore water with As concentration of $2000 \mu \mathrm{g} / \mathrm{L}$ into the overlying river water column. The association of high As concentrations in the downstream river during summer sampling (Figures 4) could be the result of lower flow rates in the summer (Figure 2) and a higher contribution of the subsurface and LCACs-rich solutions. This conclusion is consistent with 


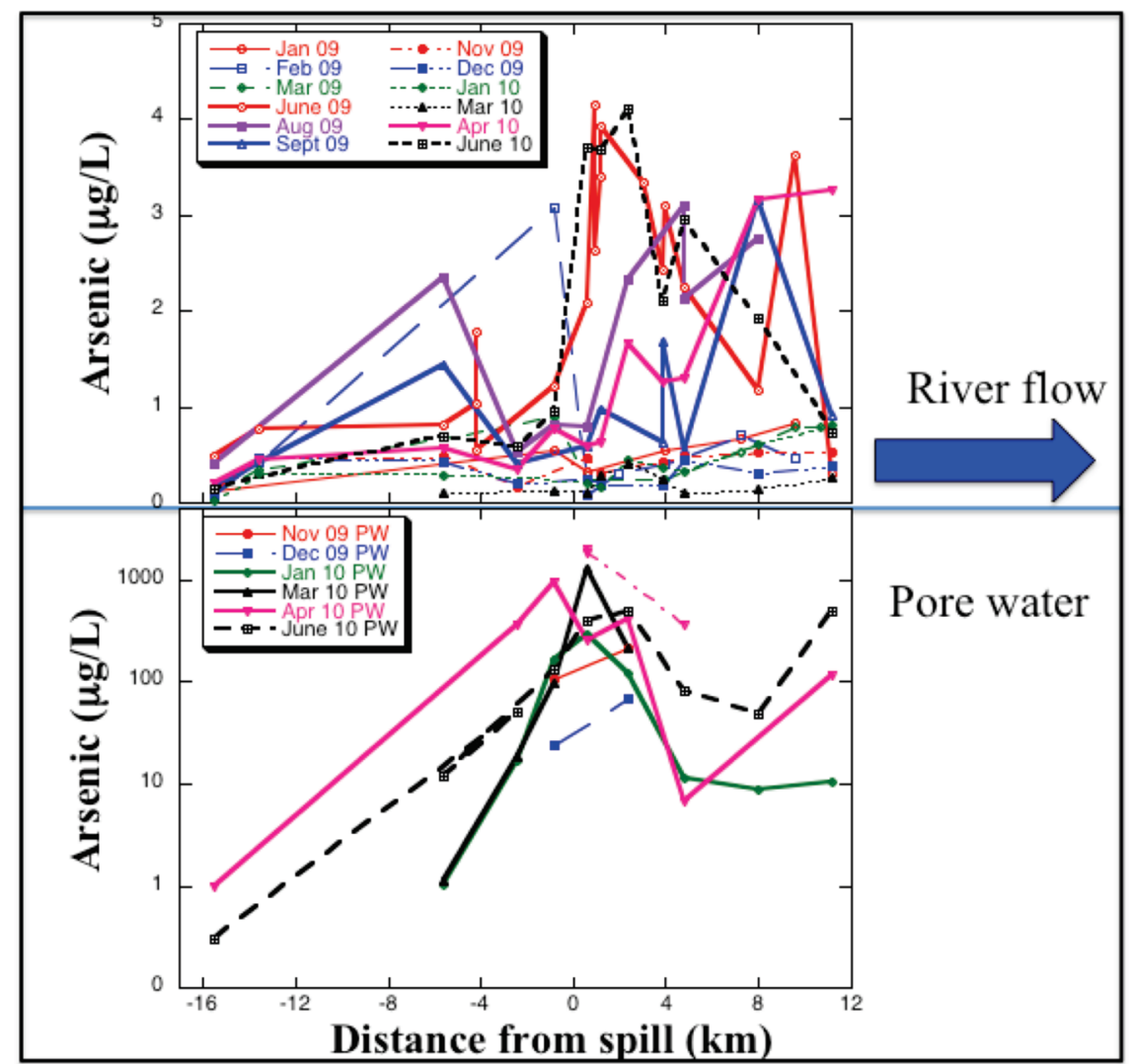

FIGURE 4. Spatial and temporal variations of As concentrations in filtered river water (top) and filtered pore water (bottom) as a function of distance from the spill site (defined as zero). Note that summer sampling yielded higher As contents in downstream river and that As in pore water increases with time in further downstream sites.

our leaching experiments (Figure 3) that show negligible As concentrations in effluents containing TVA ash in an amount that is equivalent to the typical TSS values in the Clinch and Emory Rivers (32, 33).

Implications for Tracing and Prediction of CCR Contaminants. The data presented in this study indicate that the massive remediation efforts of TVA by dredging and removing over two million cubic meters of coal ash from the Emory and Clinch Rivers had only a minor effect on the river surface water quality because of the large dilution and the low ash/water ratios, as demonstrated in our leaching experiments (Figure 3). Our data show that buried TVA ash that accumulated within the river bottom sediments with limited exchange with the surface river flow is highly reactive and generated high levels of dissolved As, B, Sr, and $\mathrm{Ba}$ in the associated pore waters. While the presence of these elements in high concentrations in the pore water presents a potential direct threat to infaunal species that live in the subsurface, particularly due to the high toxicity of the As ${ }^{\mathrm{III}}$ species $(9,49)$, the abundance of these tracers in pore waters might be used to assess the distribution and extent of buried ash in different locations downstream of the spill area in Kingston, TN.

The results of this study indicate that CCR leaching would be expected to vary for different conditions, particularly ash/ water ratio, $\mathrm{pH}$, and redox conditions. Oxygenated surface waters in contact with coal ash are expected to be enriched in many LCACs, including As and Se, whereas reducing subsurface waters (groundwater and pore waters in landfills and river sediments) are expected to be more enriched in As and depleted in Se. In contrast, the redox conditions have no apparent impact on the differential mobilization of B and Sr, which makes those elements good tracers for CCR leaching to aquatic systems. Effects of $\mathrm{pH}$ vary depending on whether the predominant form of an element in natural waters is an oxyanion or hydrated cation; elements such as B, As, and Se that occur as oxyanions exhibit higher solubility, and thus greater leachability under low and high $\mathrm{pH}$ conditions, while the solubility of most cationic species (e.g., $\mathrm{Ca}$ and $\mathrm{Sr}$ ) decreases with increasing $\mathrm{pH}$. The EPA Toxicity Characteristic Leaching Procedure (TCLP) (50), which is used to determine whether a material must be regulated as a hazardous waste, only considers leaching in weakly acidic conditions $(\mathrm{pH} \sim$ 4 ), and does not consider leaching of contaminants under a wide range of $\mathrm{pH}$ conditions $(29,30)$, nor possible anaerobic conditions. In the case of coal ash waste, our results indicate that the TCLP test would greatly underestimate leachate concentrations of As for anaerobic disposal conditions, thus would underestimate the potential impact of coal ash leachate in many situations. Future studies should focus on evaluating the potential ecological ramifications, particularly for infaunal species that would be exposed to As ${ }^{\mathrm{III}}$ in the shallow pore waters. Finally, future prognoses of the potential environmental hazards of CCRs and possible migration and fate of ash contaminants in water resources should take into account the results of investigations of the TVA coal ash spill in Kingston, TN.

\section{Acknowledgments}

This study was supported by the National Science Foundation (Division of Earth Science; EAR No. 0935972). We acknowledge the generous gift of Fred and Alice Stanback, which supported the early phase of this work. We thank the associate editor, three anonymous reviewers, and Neil Carriker for their critical and through review and helpful comments that significantly improved the earlier version of the manuscript. We also thank Neil Carriker and Bill Rogers of Tennessee Valley Authority, Adam Johnson and the RSI sampling teams, and the Environmental Standards Inc. QA oversight teams for their advice, providing the VibeCore sampler, and assis- 

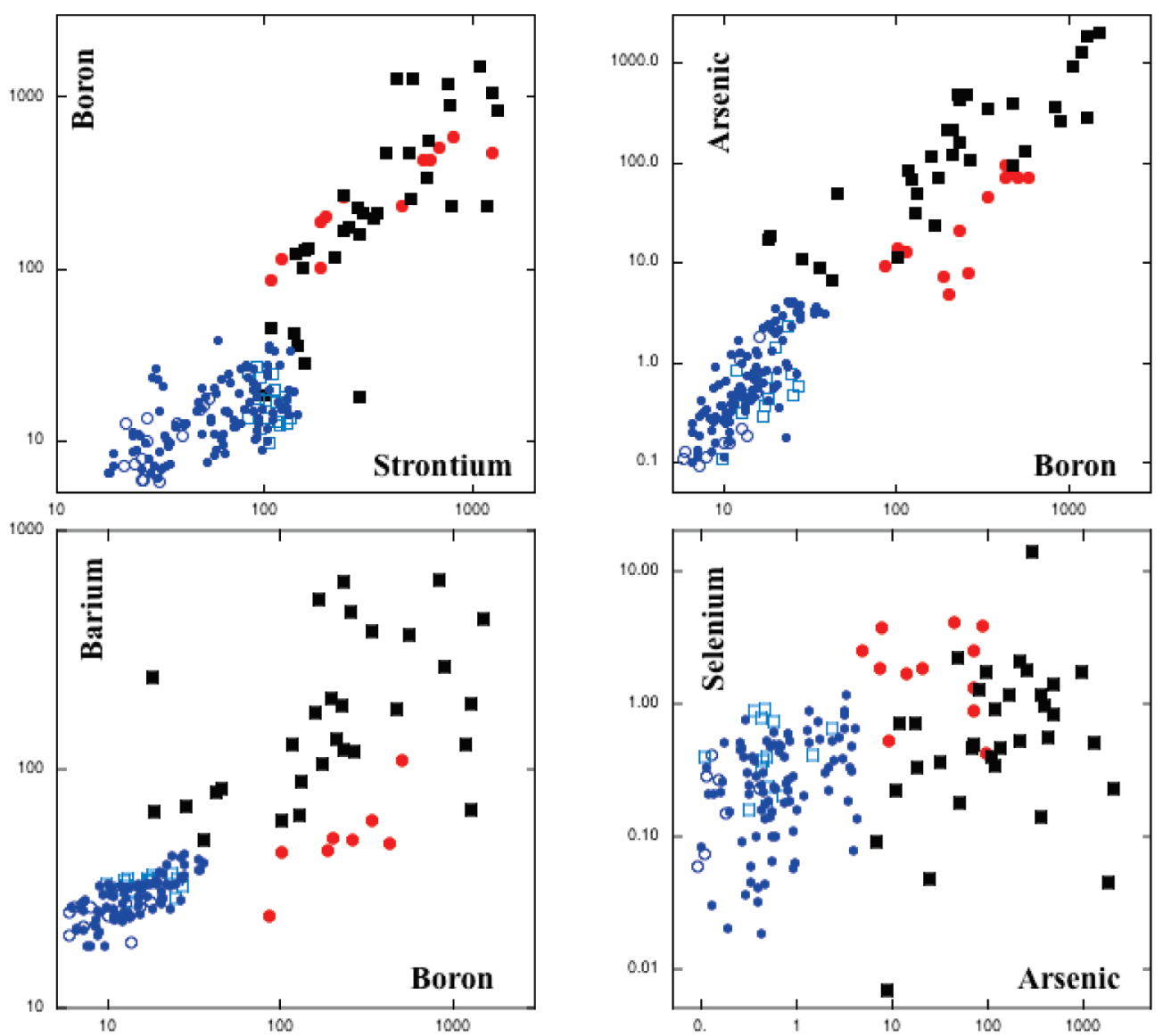

FIGURE 5. Variations of B, Sr, As, Ba, and Se concentrations ( $\mu \mathrm{g} / \mathrm{L}$ unit, logarithmic scale) in pore water (black squares), Cove water (red circles), upstream river (open squares), and downstream river (blue circles). Note the relative enrichment of As and depletion of Se in pore water relative to the Cove water.
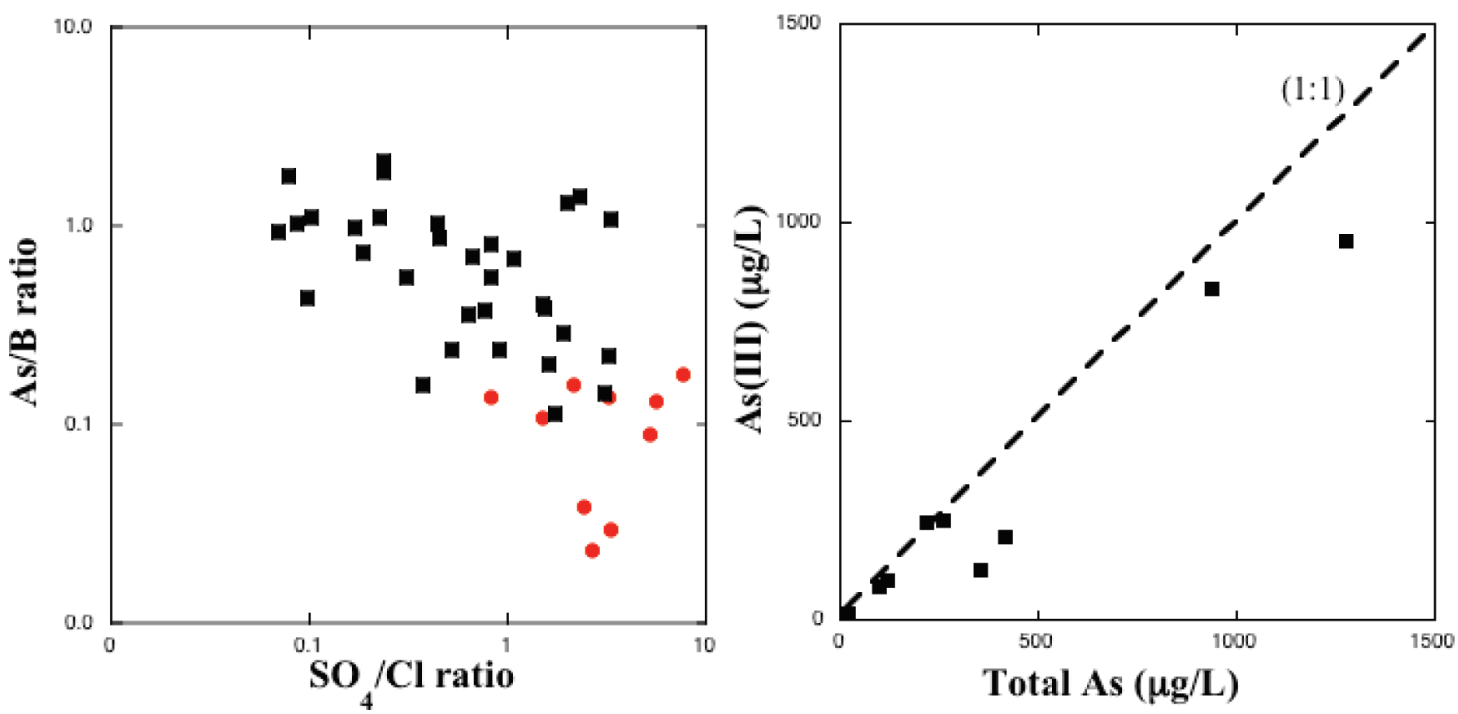

FIGURE 6. As ${ }^{\text {III }}$ versus total As measurements in pore water samples from the spill site in Kingston, $\mathrm{TN}$ (right) and $\mathrm{As} / \mathrm{B}$ versus $\mathrm{SO}_{4} /$ $\mathrm{CI}$ ratios in pore water (black squares) and Cove water (red circles; left). Note that As species in most of the pore water is dominated by the reduced As ${ }^{\text {III }}$ species and that As enrichment is associated with sulfate depletion in the pore water relative to the Cove water.

tance in sampling. We would also like to thank A. Freitag, A. Nunnery, B. R. Merola, and H. Freedman for their assistance in the field.

\section{Supporting Information Available}

Description of the analytical techniques, details on coal ash leaching experiments, and detailed chemical results. This material is available free of charge via the Internet at http:// pubs.acs.org.

\section{Literature Cited}

(1) Tennessee Valley Authority. Corrective action plan for the TVA Kingston fossil plant ash release. http://www.tva.gov/kingston/ admin_record/pdf/G/G4.pdf. 
(2) Ruhl, L.; Vengosh, A.; Dwyer, G. S.; Hsu-Kim, H.; Deonarine, A.; Bergin, M.; Kravchenko, J. Survey of the potential environmental and health impacts in the immediate aftermath of the coal ash spill in Kingston, Tennessee. Environ. Sci. Technol. 2009, 43, $6326-6333$.

(3) EPA, U. National Primary Drinking Water Regulations, EPA 816F-09-004; U.S. Environmental Protetion Agency: Washington, DC, 2009.

(4) U.S. Environmental Protection Agency. National Reccommended Water Quality Criteria. http://www.epa.gov/ost/ criteria/wqctable/ (accessed July 15, 2010).

(5) Mardon, S. M.; Hower, J. C. Impact of coal properties on coal combustion by-product quality: examples from a Kentucky power plant. Int. J. Coal Geol. 2004, 59, 153-169.

(6) Swaine, D. J. Trace-elements in coal and their dispersal during combustion. Fuel Process Technol. 1994, 39 (1-3), 121-137.

(7) Swaine, D. J. Environmental aspects of trace-elements in coal. Environ. Geochem. Health 1992, 14 (1), 2-2.

(8) Meij, R. Trace elements behavior in coal fired power plants. Fuel 1994, 39, 199-217.

(9) Yudovich, Y. E.; Ketris, M. P. Arsenic in coal: A review. Int. J. Coal Geol. 2005, 61, 141-196.

(10) Cornelis, G.; Johnson, C. A.; Gerven, T. V.; Vandecasteele, C. Leaching mechanisms of oxyanionic metalloid and metal species in alkaline solid wastes: A review. Appl. Geochem. 2008, 23, 955-976.

(11) Hower, J. C.; Sakulpitakphon, T.; Trimble, A. S.; Thomas, G. A.; Schram, W. H. Major and minor element distribution in a coalfired utility boiler in KY. Energy Sources 2006, 28 (A), 79-95.

(12) Sakulpitakphon, T.; Hower, J. C.; Trimble, A. S.; Schram, W. H.; Thomas, G. A. Arsenic and mercury partitioning in fly ash at a Kentucky power plant. Energy Fuels 2003, 17 (4), 1028-1033.

(13) Hower, J. C.; Graham, U. M.; Dozier, A.; Tseng, M. T.; Khatri, R. A. Association of the sites of heavy metals with nanoscale carbon in a Kentucky electrostatic precipitator fly ash. Environ. Sci. Technol. 2008, 42, 8471-8477.

(14) Hower, J. C.; Robl, T. L.; Anderson, C.; Thomas, G. A.; Sakulpitakphon, T.; Mardon, S. M.; Clark, W. L. Characteristics of coal combustion products (CCP's) from Kentucky power plants, with emphasis on mercury content. Fuel 2005, 84, 13381350.

(15) Querol, X.; Fernandez-Turiel, J. L.; Lopez-Soler, A. Trace elements in coal and their behavior during combustion in a large power station. Fuel 1995, 71 (3), 331-343.

(16) Elseewi, A. A.; Page, A. L.; Grimm, S. R. Chemical characterization of fly-ash aqueous systems. J. Environ. Qual. 1980, 9, 424-428.

(17) Jankowski, J.; Ward, C. R.; French, D.; Groves, S. Mobility of trace elements from selected Australian fly ashes and its potential impact on aquatic ecosystems. Fuel 2006, 85, 243-256.

(18) Rowe, C. L.; Hopkins, W. A.; Congdon, J. D. Ecotoxicological implications of aquatic disposal of coal combustion residues in the United States: A review. Environ. Monit. Assess. 2002, 80 (3), 207-276.

(19) Kashiwakura, S.; Kubo, H.; Kumagai, Y.; Matsubae-Yokoyama, K.; Nakajima, K.; Nagasaka, T. Removal of boron from coal fly ash by washing with $\mathrm{HCl}$ solution. Fuel 2009, 88 (7), 1245-1250.

(20) Dutta, B. K.; Khanra, S.; Mallick, D. Leaching of elements from coal fly ash: Assessment of its potential for use in filling abandoned coal mines. Fuel 2009, 88 (7), 1314-1323.

(21) Skodras, G.; Grammelis, P.; Prokopidou, M.; Kakaras, E.; Sakellaropoulos, G. Chemical, leaching and toxicity characteristics of CFB combustion residues. Fuel 2009, 88 (7), 12011209.

(22) Fulekar, M. H.; Dave, J. M. Heavy-metals release from ash ponds to soil-water environment-A simulated technique. Environ. Int. 1992, 18 (3), 283-295.

(23) Warren, C. J.; Dudas, M. J. Leaching behaviour of elected traceelements in chemically weathered alkaline fly-ash. Sci. Total Environ. 1988, 76 (2-3), 229-246.

(24) U.S. Geological Survey. National Field Manual for the Collection of Water-Quality Data. http://water.usgs.gov/owq/FieldManual/ index.html (accessed January 1, 2010).

(25) Bednar, A. J.; Garbarino, J. R.; Ranville, J. F.; Wildeman, T. R. Preserving the distribution of inorganic arsenic species in groundwater and acid mine drainage samples. Environ. Sci. Technol. 2002, 36 (10), 2213-2218.

(26) Allen, H. E.; Fu, G.; Deng, B. Analysis of acid volatile sulfide (AVS) and simultaneously extracted metals (SEM) for the estimation of potential toxicity in aquatic sediments. Environ. Toxicol. Chem. 1993, 12 (8), 1441-1453.
(27) Bowles, K. C.; Bell, R. A.; Ernste, M. J.; Kramer, J. R.; Manolopoulos, H.; Ogden, N. Synthesis and characterization of metal sulfide clusters for toxicological studies. Environ. Toxicol. Chem. 2002, 21 (4), 693-699.

(28) U.S. Geological Survey. USGS Real- Time Data for 03540500 Emory River at Oakdale, TN. http://waterdata.usgs.gov/usa/ nwis/uv?site no $=03540500$.

(29) Thorneloe, S. A.; K, D. S.; Sanchez, F.; Garrabrants, A. C.; Helms, G. Evaluating the fate of metals in air pollution control residues from coal-fired power plants. Environ. Sci. Technol. 2010, 44, 7351-7356.

(30) Hesbach, P. A. K., A.G.; Abel, A. S. P.; Lamey, S. C. Serial batch leaching procedure for characterizaton of coal fly ash. Environ Monit Assess 2010, 168, 523-545.

(31) Francendese, L. Memorandum: Dredging Determination 3/5/ 10. 2010.

(32) Authority, T. V. TVA Water Testing Results, revised 12/2/2009; Tennessee Valley Authority: Knoxville, TN, 2009.

(33) Authority, T. V. Maximum Value Sampling Results; Tennessee Valley Authority: Knoxville, TN, 2010.

(34) Tennessee Valley Authority. Continuing Investigation of the Nature and Extent of Ash in the Emory, Clinch and Tennessee River Bottoms. http://www.tva.com/kingston/ash_distribution.pdf.

(35) ERDCWES. Summary of ERDCWES Model Simulations. http:// www.epakingstontva.com/Nature $\% 20$ and\%20Extent/ Summary\%20of\%20Storm\%20Events.doc.pdf.

(36) Adriano, D. C.; Page, A. L.; Elseewi, A. A.; Chang, A. C.; Straughan, I. Utilization and disposal of fly-ash and other coal residues in terrestrial ecosystems-A review. J. Environ. Qual. 1980, 9 (3), 333-344.

(37) Elseewi, A. A.; Straughan, I. R.; Page, A. L. Sequential cropping of fly-ash amended soils-Effects on soil chemical properties and yeild and elemental composition of plants. Sci. Total Environ. 1980, 15 (3), 247-259.

(38) Landsberger, S.; Cerbus, J. F.; Larson, S. Elemental characterization of coal ash and its leachates using sequential extraction techniques. J. Radioanal. Nucl. Chem.-Artic. 1995, 192 (2), 265274.

(39) Huggins, F. E.; Helble, J. J.; Shah, N.; Zhao, J.; Srinivasachar, S.; Morency, J. R.; Lu, F.; Huffman, G. P. Forms of occurrence of arsenic in coal and their behavior during coal combustion. Abstr. Pap. Am. Chem Soc. 1993, 205, 12.

(40) Huggins, F. E. H., G.P.; Miller, C. A.; Linak, W. A. Leaching and XAFS Characterization pf PM 2.5 from Combustion of U.S. Coals; International Ash Utilization Symp: Lexington, KY, 20-22 October 2003.

(41) Huggins, F. E.; Senior, C. L.; Chu, P.; Ladwig, K.; Huffman, G. P. Selenium and arsenic speciation in fly ash from full-scale coalburning utility plants. Environ. Sci. Technol. 2007, 41 (9), 32843289.

(42) Shoji, T.; Huggins, F. E.; Huffman, G. P.; Linak, W. P.; Miller, C. A. XAFS spectroscopy analysis of selected elements in fine particulate matter derived from coal combustion. Energy Fuels 2002, 16 (2), 325-329.

(43) Plant, J. A.; Kinniburgh, D. G.; Smedley, P. L.; Fordyce, F. M.; Klinck, B. A., Arsenic and Selenium. In Teatrise in Geochemistry; Holland, H. D., Turekian, K. K., Lollar, B. S., Eds.; ElsevierPergamon: Oxford, 2003; Vol. 9, pp 17-66.

(44) Wolthers, M.; C, L.; van Der Weijden, C. H.; van der Linde, P. R.; Rickard, D. Arsenic mobility in the ambient sulfidic environment: Sorption of arsenic(V) and arsenic(III) onto disordered mackinawite. Geochim. Cosmochim. Acta 2005, 69 (14), 3483-3492.

(45) Raven, K. P.; Jain, A.; Loeppert, R. H. Arsenite and arsenate adsorption on ferrihydrite: Kinetics, equilibrium, and adsorption envelopes. Environ. Sci. Technol. 1997, 32, 344-349.

(46) Dzombak, D. A.; Morel, F. M. M. Surface Complexation Modeling-Hydrous Ferric Oxide: Wiley: New York, 1990.

(47) Bar Yossef, B. a. M., D. Selenium sorption by kaolinite and montmorillonite. Soil Sci. 1987, 144, 12-19.

(48) White, A. F.; Dubrovsky,N. M. Chemical oxidation-reduction controls on selenium mobility in groundwater systems. In Selenium in the Environment; Frankenberger, W. T., Benson, S., Eds.; Marcel Dekker, Inc.: New York, 1994; Vol. Chp 8, pp185221.

(49) Duker, A. A.; Carranza, E. J. M.; Hale, M. Arsenic geochemistry and health. Environ. Int. 2005, 31 (5), 631-641.

(50) Toxicity Characteristic Leaching Procedure, Method 1311; U.S. Environmental Protection Agency: Washington, DC, 1992.

ES1026739 